\title{
熱膨張性耐火ゴム
}

\author{
久重 光 人*1. 斉藤 清 高 $* 2$. 和 田秀 一 $* 3$
}

\section{Heat Expansion Fireproof Rubber}

Mitsuto HISASHIGE, Kiyotaka SAITO, Syuuichi WADA(CRK Co., Ltd., 306 Koyagi-machi, Takasaki, Gunma 370-0071, Japan)

As for fireproof rubbers in Japan, a fireproof putty has been used for 30 years as a fire spreading prevention material in the district crack penetration part of the communication cable and the electric cable.

Recently heat expansion fireproof sponge has been used because of its recyclability and workability. On the other hand, various heat expansion fireproof rubbers have been developed as materials that take the place of asbestos. They are beginning to be used for wide fields like iron frame covered materials, fireproof packings and fire wall joint materials. Most of these rubbers do not contain halogen compounds, so they are environment- friendly materials that do not generate harmful flue gases (hydrogen cyanide and hydrogen chloride, etc) in case of fire.

Key Words : Fireproof Rubber

\section{1.は じめ に}

約 30 年前より通信ケーブルの延焼防止材として，ビル や集合ケーブルの防火区画貫通部用に耐火パテが使われて 来た。耐火材は実際に火災が発生しないとその効果が確認 できないが，不幸なできごとであるが1984年11月東京の 世田谷で起きた地下ケーブル火災事故では耐火パテによっ て，延焼拡大が防止できた。この結果，耐火パテの効果が 再認識され, その後着実に使用が拡大している. 数年前よりリサイクル性を考慮し耐火スポンジ 材が開発され，この分野で着実に耐火パテから の置き換えが進んでいる。一方 2002 年の建築 基準法改正で，従来準不燃材料以上という制約 があり，耐火被覆材は無機系材が前提であった が材料制限が撤廃され，有機系の材料が使用可 能となった：相前後して，建物に使われていた アスベストの発がん性問題が発生し，環境対策 より熱膨張性耐火ゴムで鉄骨を被覆する製品が 開発され，ゴム加工メーカーを中心に材料開発 が行われ，着実に耐火被覆材分野の一角を占め るまでになってきつつある.

\section{2. 各種耐火ゴム}

現在市販されている各社の耐火ゴム製品のラ インナップ状況は流動的で正確性に少し欠ける
面があるが，大別すると表 1 に要約される.

様々な耐火ゴムが製品化されておりこれらを図 1 に示

表 1 市販耐火ゴム製品

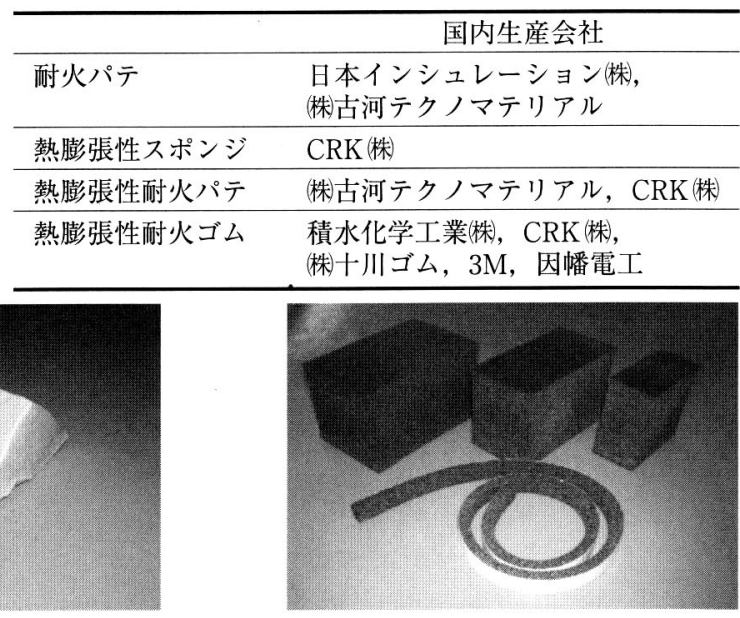

耐火パテ>

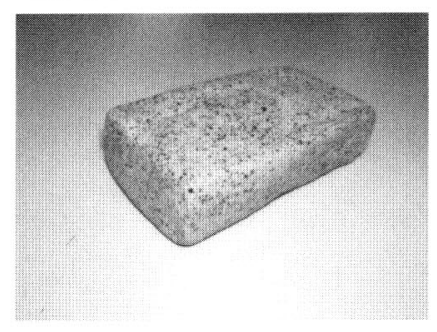

熱膨張 性而火我 パ >
<熱膨張性スポンジ>

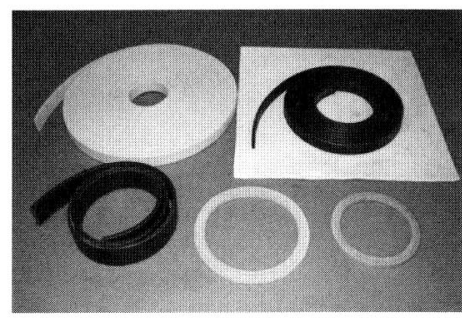

$<$ 熱膨張性耐火ゴム>
四 1 耐火ゴム製品例 
す.

これらの耐火ゴムの中で最近注目を集めている熱膨張性 スポンジと熱膨張性耐火ゴムを中心に，耐火ゴムの状況に ついて報告する。

\section{3. 耐火 パ テ}

耐火パテは, 熱膨張性ではないが，熱膨張性耐火ゴムの ベースとなっている材料である. 液状ゴムをバインダーと し難燃剂として水酸化アルミニウム等を加え，形状保持に 繊維状物質を加えている。性状は粘土状で, 酸素指数が 70 以上もありほとんど然えない.手で粘土細工の様に 色々な形に作り上げる事ができる．製品の中には予め色々 な形状にしてそれをビニル袋に入れ，手を活さずにそれら の組み合わせでケーブルをシールできるものもある．用途 は主にケーブルホールの防火区画貫通部に於けるケーブル の延焼防止の目地材であり，30年前から使われている. また, 空調機の冷媒配管の目地材としても用いられている.

\section{4. 熱膨張性耐火パテ}

耐火パテは加熱しても膨張しないのに対し，熱膨張性耐 火パテは $200{ }^{\circ} \mathrm{C}$ 以上で $5 \sim 6$ 倍に膨張する. それ以外の性 状は耐火パテとあまり変わらない。用途はケーブルや冷媒 配管の延焼防止用の目地材である. 加熱すると膨張する事 により，壁等のケーブル貫通部の延焼防止材として使用さ れている1).

\section{5. 熱膨張性スポンジ}

熱膨張性黒鉛及び数種類の難燃剂を高充てんさせ，ベー スゴムにウレタンを用い，製品は予め約 3 倍位に発泡させ スポンジ状にしている．火災などの高温 $\left(200{ }^{\circ} \mathrm{C}\right.$ 以上)に曝 されると更に速やかに膨張し, ガラス状の強固な膨張層を 形成する．材料に含まれている難燃剤との相乗効果で，よ り高い難然性を発現する材料である。

本スポンジの膨張倍率は約 4 倍位でグレードとして一般 タイプと耐久性タイプの雨方がある. 充てん剤はハロゲン 化合物を含まないため，燃焼時に有毒ガスの発生が少ない 材料である．製品は予め施工し易いように所定の寸法に加

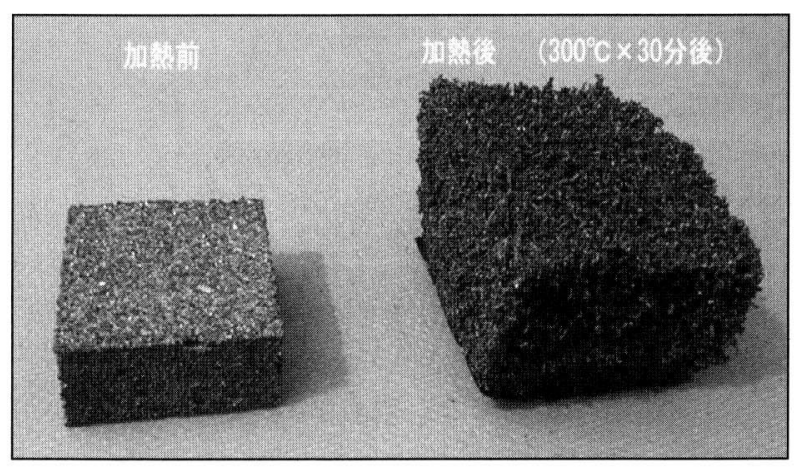

図 2 熱膨張性スポンジの加熱処理前後
工されているが，施工現場でも容易に加工できる，その際 に発塵せず，皮膚に触れても痒み，痛み等も無く，人・作 業環境及び長期安定性に優れ，長期使用でも発塵する事は 無い。施工も簡単で，短時間にケーブルの周りにブロック を積み木細工の様に置いていくだけである。しかし，火災 になるとスポンジが膨張し煙も通過出来なくなる位に密閉 化するので，火災にあったケーブルも延焼が止められ，延 焼防止が可能となる.

従来から使われている耐火パテとの比較を表 2 に示す.

熱膨張性スポンジは耐火パテの課題であるリサイクル性 と作業時間を短縮化する等の従来からの課題を解決した優 れた材料で, 着実に耐火パテからの置き換えが進んでいる. 以下に熱膨張性スポンジの特色ある物性値を示す。

\section{1 断熱性}

熱膨張性スポンジは常温ではスポンジ構造を持ってお り, 他の発泡体と変わらない断熱性を保持している. 更に, 火災の際には熱膨張し材料の厚みが増し，断熱性が一層向 上する。一方, 熱膨張性耐火ゴムは熱膨張後にはスポンジ 同等の熱伝導率となる．耐火パテの代用として開発された が高い断熱性を活用できる分野にも用途展開が図れる。

表 3 に各材料の熱伝導率データを示す.

\section{2 難燃性}

\section{2 .1 酸素指数}

難燃性を示す酸素指数 (JIS K7201：材料が燃焼し続け るのに必要な最少酸素濃度であり，数值が大きいほど高い 難然性であることを示す数值) は一般夕イプで70以上と非 常に高い難燃性を示しており，耐久性タイプでも 45 であ る(表 4).これは耐久性タイプでも難燃性の高いポリ塩化 ビニルを超える難燃性である。

表 2 耐火パテと熱膨張性スポンジの比較

\begin{tabular}{lccc}
\hline 材 料 & 比 重 & 施工(作業)時間 & リサイクル性 \\
\hline 而火パテ & $1.8 \sim 2.10$ & 基準 & 使い捨て \\
\hline 熱膨張性スポンジ & $0.2 \sim 0.35$ & 基準の $1 / 5$ & 再利用が可能 \\
\hline
\end{tabular}

表 3 各種材料の熱伝導率

\begin{tabular}{lc}
\hline \multicolumn{1}{c}{ 材 料 } & 熱伝導率 $(\mathrm{W} / \mathrm{m} \cdot \mathrm{K})$ \\
\hline 熱膨張性スポンジ & $0.08 \sim 0.10$ \\
\hline 熱膨張性耐火ゴム & $0.25 \sim 0.80$ \\
\hline 熱膨張後の耐火ゴム & $0.10 \sim 0.12$ \\
\hline ウレタンフォーム & 0.03 \\
\hline ポリ塩化ビニル $(\mathrm{PVC})$ & $0.16 \sim 0.17$ \\
\hline
\end{tabular}

表 4 酸素指数 ${ }^{2)}$ の比較

\begin{tabular}{ll}
\hline \multicolumn{1}{c}{ 材料 } & 酸素指数 \\
\hline 熱膨張性スポンジ & 70 以上 \\
\hline 熱膨張性スポンジ(耐久性タイプ) & 45 \\
\hline エチレンープロピレンゴム & 22 \\
\hline ウレタンフォーム & 21 \\
\hline 一般シリコーン & 25 \\
\hline ポリ塩化ビニル $(\mathrm{PVC})$ & 42 \\
\hline
\end{tabular}




\section{2 .2 燃焼性評価}

ASTM 及びBS 規格試験を実施し「炎の非拡散性」では 燃焼時に炎の拡散が少なく難燃性(ASTM E162合格), 「低発煙性」では燃焼時に煙の発生が抑制される(ASTM E662 合格)，「火炎伝播長さ」では規格值以下である (ASTM C1166合格)。BSではBS476(Part7 試験でClass2) 鉄道車両用材料燃焼試験で難燃区分を取得している.これ らの結果及び後ほど述べる燃焼時の低有毒ガス性の評価で 良好である事より, 台湾新幹線の車両の防火壁目地材とし て世界中の材料の中で熱膨張性スポンジが採用になった。

\section{3 安全性}

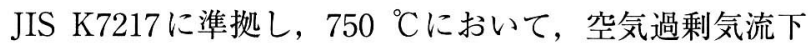
表 5 燃焼評価データ

\begin{tabular}{|c|c|c|c|c|c|}
\hline \multicolumn{3}{|l|}{ 試験項目 } & 測定値 & 規格値 & 試験方法 \\
\hline \multicolumn{3}{|c|}{ ※1 火炎伝播インデックス } & 16 & $<35$ & ASTM E162 \\
\hline \multirow{4}{*}{$\begin{array}{l}※ 2 \\
\text { 発煙濃度 } \\
\text { (Ds) }\end{array}$} & \multirow[t]{2}{*}{ 有炎 } & 1.5 分 & 11 & $<100$ & \multirow{4}{*}{ ASTM E662 } \\
\hline & & 4.0 分 & 40 & $<200$ & \\
\hline & \multirow[t]{2}{*}{ 無炎 } & 1.5 分 & 28 & $<100$ & \\
\hline & & 4.0 分 & 66 & $<200$ & \\
\hline \multicolumn{3}{|c|}{ ※ 3 火炎伝播長さ (inch) } & 0.5 & $<4$ & ASTM C1166 \\
\hline
\end{tabular}

※ 1 火炎伝播インデックス

燃焼時の炎の拡散性を示す指標で, 低い方が非拡散性を示してい る.

$※ 2$ 発煙濃度

燃焼時，発生した煙を光透過率の減衰量を測定し，発煙量の値と している.

※ 3 火炎伝播長さ

密に又は一定の区画に納まったゴム化合物が熱や炎に接し火炎伝 播する值を表す。
(完全燃焼条件)および空気不足気流下 (不完全燃焼条件)で 発生する燃焼ガス $\left(\mathrm{CO}, \mathrm{CO}_{2}, \mathrm{HCl}, \mathrm{HCN}\right.$ 等) を検査した。 その結果, 表 6 の如く有害ガスがほとんど検出されていな い. 問題となるハロゲン系ガスも検出されていない. 硫黄 酸化物が若干検出されているのは充てん剂に含まれている 不純物からの発生と考えられる。

\section{4 長期寸法安定性}

熱膨張性スポンジは約 3 倍発泡体で, 時間経過とともに 形状が変形する事が無いか高さ $10 \mathrm{~cm} \times$ 幅 $10 \mathrm{~cm} \times$ 長さ 15 $\mathrm{cm}$ の耐火スポンジを $50{ }^{\circ} \mathrm{C}$ のギアオーブンの中に保管し寸 法安定性を評価した。 その結果図 3 に示すように, 幅と長 さ方向はほとんど変化が無く, 高さ方向に 12 か月後で $1 \% の$ 変化であった。 この結果, 長期寸法安定性にも優れ た物であることが分った。

\section{5 用途展開}

\subsection{1防火区画貫通部延焼防止用途}

熱膨張性スポンジはケーブルの区画貫通部の延焼防止材 を目的に開発され, 現在は高層ビルを始めとする各種通信

表 6 燃焼ガス組成データ（試験法：JIS K7201）

\begin{tabular}{ccc}
\hline 燃焼ガス組成 & 完全燃焼下 & 不完全燃焼下 \\
\hline 塩化水素 & 検出せず & 検出せず \\
\hline シアン化水素 & 検出せず & 検出せず \\
\hline アンモニア & 検出せず & 検出せず \\
\hline 硫黄酸化物 & $13 \mathrm{mg} / \mathrm{g}$ & $10 \mathrm{mg} / \mathrm{g}$ \\
\hline 一酸化炭素 & 検出せず & 検出せず \\
\hline 二酸化炭素 & $800 \mathrm{mg} / \mathrm{g}$ & $900 \mathrm{mg} / \mathrm{g}$ \\
\hline
\end{tabular}

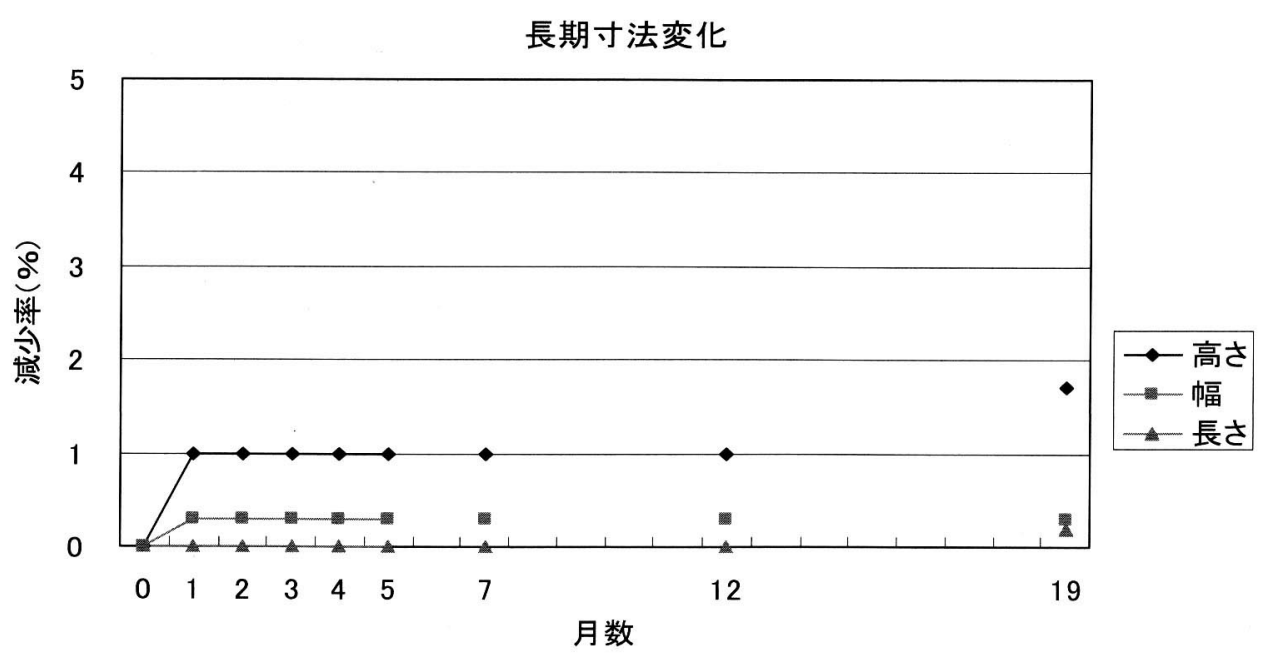

図 3 熱膨張性スポンジの長期寸法安定性

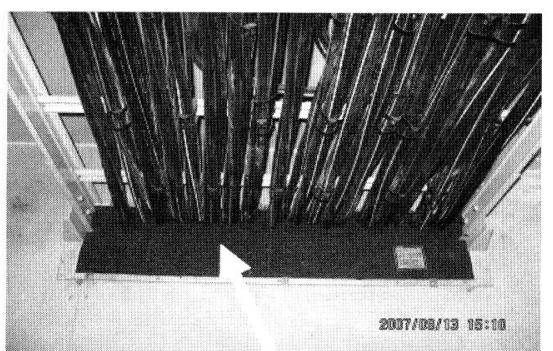

国交省認定番号

図 4 床貫通部への充てん 
ケーブルの区画貫通部で使用されている，床に適用した際 の構成図を図 4 に示す.

熱膨張性スポンジを用いた本工法は敷設するケーブル本 数を従来の耐火パテに比べ数十\%多くできると好評であ る.一方，熱膨張性スポンジでは火災の際，煙が通過して しまう懸念が持たれるが，建材試験センターでの耐火試験 では当初煙の発生が確認されたが, 貫通部が加熱されると, 数分後に煙は遮断され，しかもケーブルの延焼が区画貫通 部で防止されている事が良く分かる.
IT化の現在，通信ケーブルの容量増強の要請が強くな っている．耐火パテではケーブル増設の度，耐火処理をや り直さなければならなかったが，本材料は図 6 の如く，簡 単に増強ができ，取り外したスポンジは再利用ができるの で地球環境に優しい材料と好評である．施工法も充てんす るだけなので施工スピードが早く，建設工事全体の納期遅 れを解決する優れた材料でもある。本工法についてはユー ザーで国交省の耐火認定を取得している ${ }^{3)}$ (床充てん工 法：PS060FL-0030, 壁充てん工法：PS060WL-0033).

$<$ 耐火試験開始 $>$ $<$ 加熱開始 15 分後発煙 $>$
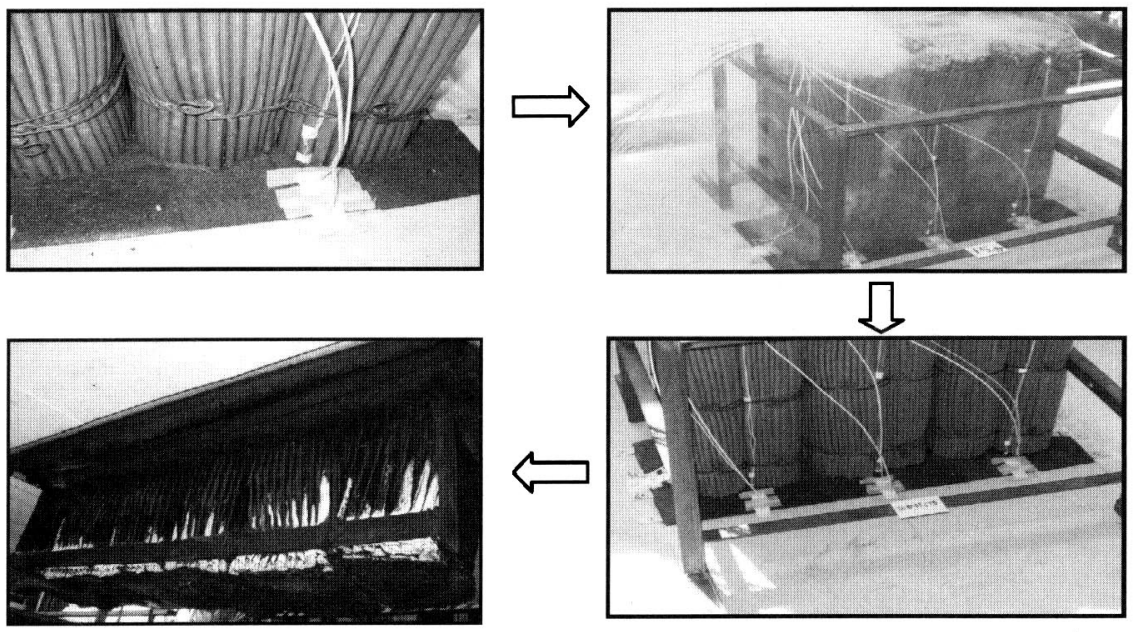

$<$ 炉内側 $>$

$<$ 煙発生後 5 分後に煙遮断 $>$ 図 5 煙遮断性能
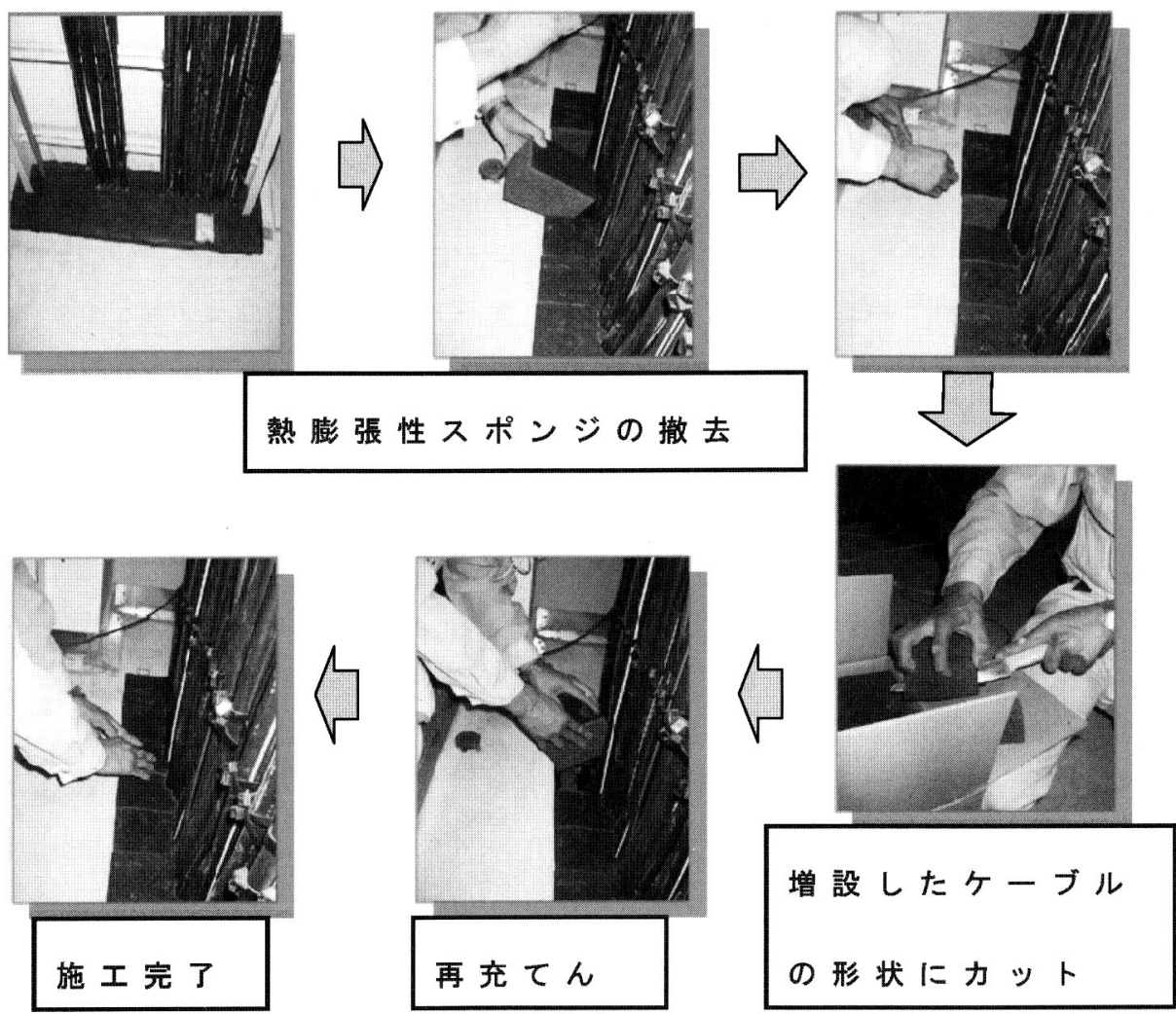

図 6 熱膨張性スポンジの施工方法 


\section{5 .2 高速鉄道車両防火壁目地材}

高速で走る鉄道の車両で火災が発生した時，延焼を防止 するため車両の防火壁目地材として熱膨張性耐火ゴムは優 れた材料といえる．既述したが台湾新幹線で使用実績がで きたことより，アメリカ，イギリスでの地下鉄車両向けに 展開が期待できる.

\section{6 リサイクル性}

本熱澎張性スポンジで加工時, 端材となった物は粉砕で 簡単に細かな粒状となる。これをウレタン原料と混合し, 加熱，成形すると新たな製品にリサイクルする事も可能で ある.図 7 の製品は熱膨張性スポンジ製品を粉砕後再成形 した物である ${ }^{4)}$. 今後, 需要に応じてリサイクル品の有効 活用も可能である.

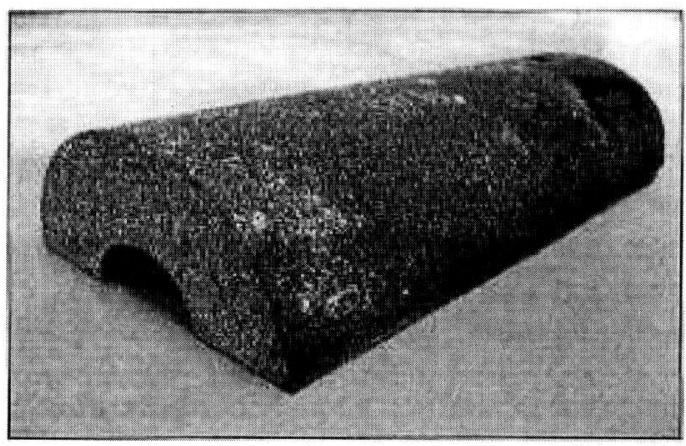

図 7 リサイクル成形品

\section{6. 熱膨張性ゴム}

熱膨張性ゴムは用途より，鉄骨被覆用とその他用途に大 別される.

\section{1 鉄骨被覆用}

鉄骨被覆用は積水化学工業社の熱膨張性ゴムシート ( イブロック $)^{5)}$ が市場で使用されている. バインダー用の ゴムはブチルゴム，ポリブテン等が用いられている．難燃 剂，形状保持剂が適量配合されている．熱膨張性黒鉛を加 え，加熱時膨張し耐火層を形成し，耐火機能を発揮させて いる.難燃剤にハロゲン含有化合物を添加していないので, ダイオキシン発生の原因となる塩素系ガスを全く発生しな い. 鉄骨被覆には用途に応じ耐火ゴム単独使用及びセッコ ウボードとの組み合わせが用いられている6).

\section{2 一般用途の熱膨張性ゴム}

鉄骨被覆以外の熱膨張性ゴムも加工性が容易な事より, 最近種々の分野に使用されて来ている．代表的な耐火ゴム はバインダーとなるゴムはEPDMを中心に用いられ，こ れに難燃剂，形状保持剂，熱膨張性黒鉛を加え熱膨張性ゴ ムにしている。この熱膨張性ゴムもハロゲン含有化合物を 添加しておらず完全燃焼下及び不完全燃焼下に於いても塩 化水素を始めシアン化水素，アンモニア等の有害なガスを 全く発生しない. 熱膨張性ゴムの物性及び燃焼時の発生ガ スの分析結果を表 7,8 に示す.
表 7 熱膨張性ゴムの物性值 (代表値)

\begin{tabular}{ccc}
\hline 試験項目 & 測定值 & 試験方法 \\
\hline 硬 度 & $\mathrm{A} 65$ & JIS K6253 \\
\hline 引張強度 & $1.2 \mathrm{MPa}$ & JIS K6251 \\
\hline 熱膨張開始温度 & $200{ }^{\circ} \mathrm{C}$ & 自社試験法 \\
\hline 熱膨張倍率 & 8 倍 & 自社試験法 \\
\hline 酸素指数 & 45 & JIS K7201 \\
\hline
\end{tabular}

酸素指数が 45 もあり,ポリ塩化ビニルの酸素指数 42 を凌いでいる，熱膨張倍率が8倍ある.

表 8 熱膨張性ゴムの燃焼ガス分析結果(JIS K7201)

\begin{tabular}{ccc}
\hline & 完全燃焼下 & 不完全燃焼下 \\
\hline 塩化水素 & 検出せず & 検出せず \\
\hline シアン化水素 & 検出せず & 検出せず \\
\hline アンモニア & 検出せず & 検出せず \\
\hline 硫黄酸化物 & $6 \mathrm{mg} / \mathrm{g}$ & $7 \mathrm{mg} / \mathrm{g}$ \\
\hline 窒素酸化物 & 検出せず & 検出せず \\
\hline 一酸化炭素 & $19 \mathrm{mg} / \mathrm{g}$ & $60 \mathrm{mg} / \mathrm{g}$ \\
\hline 二酸化炭素 & $1200 \mathrm{mg} / \mathrm{g}$ & $800 \mathrm{mg} / \mathrm{g}$ \\
\hline
\end{tabular}

熱膨張性ゴムの使用先は, 隙間充てん用途が多い.

耐火用材料同士の繋ぎ目部分や換気構造を設けた部分 (壁，軒裹，棟，軒下等の換気部）といった隙間部分は耐火 構造の弱点部となっている。熱膨張性ゴムは「火災時に膨 張して耐火断熱層を形成する」という特長を生かして，建 築物の隙間部分をこの耐火断熱層で満たす事で弱点部の耐 火性能を補強する用途に利用されている。

図 8 は免震装置の防火パネル用目地材として使われてい る事例である.

免震装置は防振ゴムでできており，燃え易いので周りを 防火パネルで井っているが，パネルの隙間に熱膨張性ゴム が貼られている。ログハウスの組み合わせの隙間部や木製 のドアにも火災時火炎が隙間から侵入しないよう，四隅を 熱膨張性ゴムでシールしている．住宅の軒下の通風口にも 最近熱膨張性ゴムが貼られている，延焼時は一般的には軒 下の通風口から火が回る場合が多く，熱で膨張し炎の侵入 を防ぐ。一方，大型金庫にも扉の四隅を熱膨張性ゴムでシ ールし火炎の侵入を防いでいる，最近首都圈を中心に高層 ビルが建設されているが，これ等のビルで使用されている

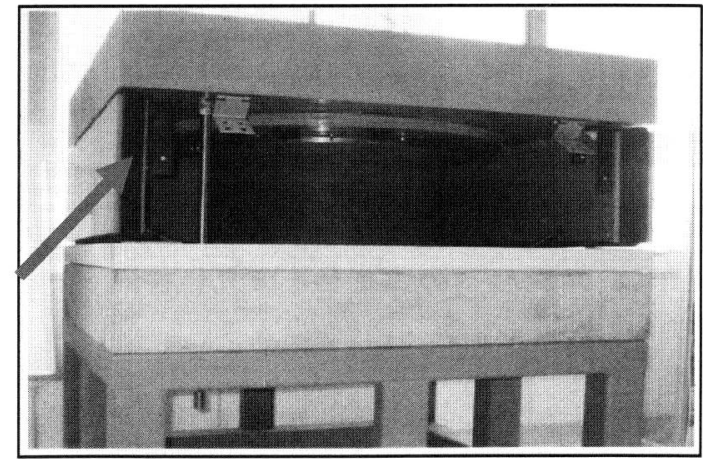

図 8 免震装置への用途例 
$8 \mathrm{~mm}$ 間隔あり

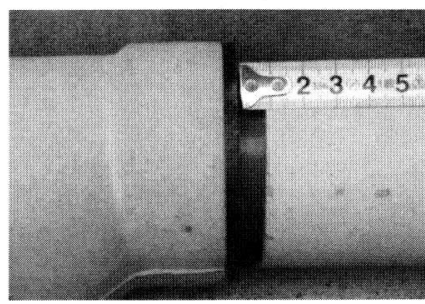

$20 \mathrm{~mm}$ 膨張 し 隙間充てん
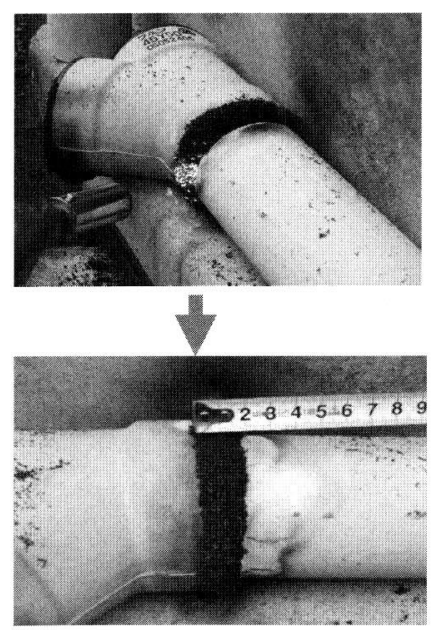

図10 耐火二層管目地材の効果

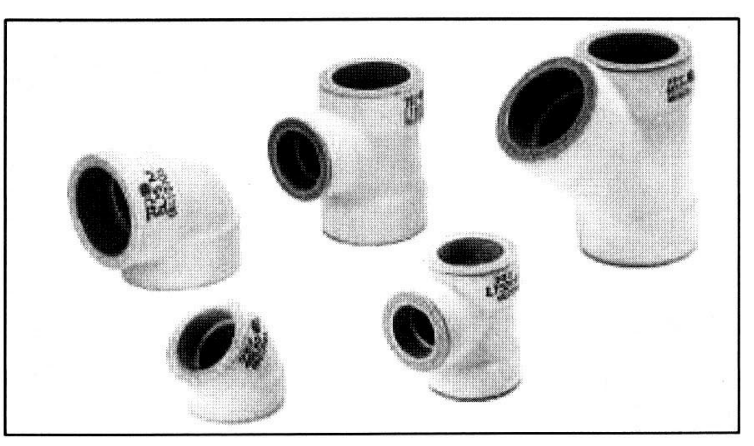

図 9 耐火二層管への用途例

排水管は塩ビ配管の表面をモルタルセメントで被覆した耐 火二層管が使われている. ビル内では各所からの排水管と メイン排水管との接続部には熱膨張性ゴムを加工した耐火 パッキンが色々な継手に数多く使われている.

図10に装着した耐火パッキンに火炎を当てた時の状況 を示す．隙間を少し開けた状態で火炎を当てた時，耐火パ ッキンが $20 \mathrm{~mm}$ 膨張し隙間を完全に充てんし，塩ビ配管 への防火が完全になされている.

\section{7. を め}

熱膨張性ゴムはゴム特有の柔軟性, 加工しやすさ，利便 性等の多くの利点がある事より，最近色々な分野に使われ るようになった，しかし，本来燃え易い性質のゴムに耐火 性を付与し顧客の要求に対応していくには課題も多い．耐 火の機能を更に追及するとともに，価格の面でも他の競合 品に比し十分競争力ある材料にしていく必要がある.

\section{References}

1) Siokawa, K.; Nakamura, M.: NTT Facilities Jounal, 38 (2000)

2) Hanai, K.; Sekiguti, T.: Showadensen Denran Review 24, 24 (1974)

3 ) Nihon Insyureisyon Kabusikikaisya Seihin Catalog "Cable Ensyou Bousi Taika Kouhou"

4) Toda, K.: Jpn Kokai Tokkyo Koho 1998-52866 (1998)
5) Okada, K.: Nippon Gomu Kyokaishi, 75, 356 (2002)

6 ) Ogasawara, M.; Tono, M.: GBRC, 111, 26 (2003)

\section{日本語表記参考文献}

1 ）塩川完也，中村三智之：NTTファシリティーズジャーナル，38 (2000)

2 ）花井節, 関口武：昭和電線電らんレビュー, 24, 24（1974）

3) 日本インシュレーション(侏製品カタログ,「ケーブル延燒防止耐 火工法」

4) 戸田健一郎：特開平 10-52866 (1998)

5 ）岡田和廣：日本ゴム協会誌，75，356 (2002)

6 ）小笠眞男, 戸野正樹：GBRC, 111, 26 (2003)

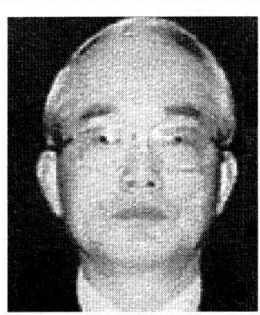

${ }^{* 1} \mathrm{CRK}$ 侏)（～３70-0071 高崎市小八木町 306) 顧 問. 昭和 43 年東北大学大学院工学研究科応 用化学科卒業, 昭和 43 年電気化学工業侏入 社, 平成 16 年 $\mathrm{CRK}$ 株式会社入社, 現在に至 る. 専門は高分子化学.

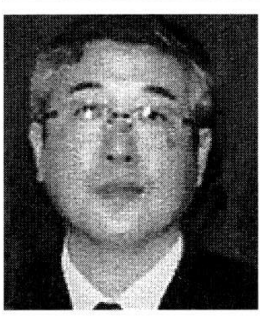

${ }^{* 2} \mathrm{CRK}$ 侏) ( ⿳ 370-0071 高崎市小八木町 306) 技 術開発部長. 昭和 51 年千葉大学大学院工学 研究科応用化学科卒業. 昭和 51 年電気化学: 工業(侏入社. 平成 14 年 $\mathrm{CRK}$ (秼)入社, 現在に 至る. 専門は高分子化学.

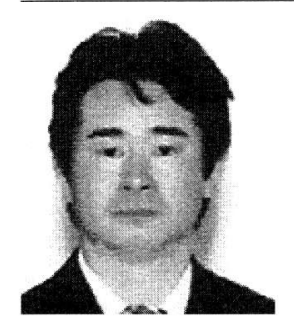

${ }^{*}{ }^{3} \mathrm{CRK}$ 株（（３70-0071 高崎市小八木町 306）技 術開発部課長代理. 平成元年, 電気化学工 業入社. 平成 6 年, $\mathrm{CRK}$ 侏入社. 